\title{
INTEGRATING FLOOD RISK ASSESSMENT INTO MANAGEMENT PRACTICE (CASE STUDY IN BULGARIA)
}

DOI: http://dx.doi.org/10.18509/GBP.2018.55

UDC: $627.516: 528.47(497.2)$

\author{
Daniela Zlatinova \\ Department Regional Development, Faculty of Geology and Geography, \\ Sofia University 'St. Kliment Ohridski', 15 tsar Osvoboditel bldv, Sofia, Bulgaria
}

\begin{abstract}
The aim of the current publication is to present a conceptual framework for integration of flood risk assessment into flood management practice in Republic of Bulgaria - the case study of Yantra River Basin.

The conceptual framework is based on the concept of flood risk, which presents risk as the combination of 'probability of flooding' and 'negative consequences' for Human health, Economy, Environment and Cultural heritage. Flood risk management is a holistic and continuous process, which includes analysis of the flood risk system (determination of current and future flood risk), the evaluation of a certain system state (judgement on risk and risk reduction alternatives) and the reduction of undesirable risk (strategic alternatives for flood risk reduction). A central place in the conceptual framework take the applied methodological approach for flood risk assessment and mapping of Yantra River Basin, which allows application of different flood risk management regimes before, during and after the flood event A number of flood risk reduction alternatives are analysed.

The major findings of the research are flood vulnerability and risk maps of the Yantra River, as well as identified interventions in the river flood-risk system based on physical measures and policy instruments.
\end{abstract}

Keywords: flood, risk assessment, risk management, $R$. Bulgaria

\section{INTRODUCTION}

Flood risk assessment gives an opportunity to the central and local authorities, business, NGO's and the general public to reach a common understanding of the flood risk which they face as a community and to promote the debate on priority measures for its prevention and reduction.

The aim of the current publication is to present a conceptual framework for integration of flood risk assessment into flood management practice in Republic of Bulgaria. The developed framework will allow application of different flood risk management regimes - before, during and after the flood event.

Yantra River as a case study of the implementation of the conceptual framework has been chosen. The considerations are related to the fact that the Yantra River refers to the most torrential river systems in Bulgaria. The catchment area combines specific natural and anthropogenic factors, which have determined catastrophic floods both in the past and in our most recent history. Their formation by the geographical location of the river basin/catchment area is determined. It is located in the central part of Northern Bulgaria and it is part of the Danube Basin. The Yantra River is its right tributary and gathers its 
waters from the northern slopes of the Middle Stara Planina Mountain and the Fore Balkan.

\section{MATERIAL AND METHODS / METHODOLOGY}

The conceptual framework is based on the concept of flood risk, which presents risk as the combination of 'probability of flooding' and 'negative consequences' for Human health, Economy, Environment and Cultural heritage. Flood risk management is a holistic and continuous process, which includes analysis of the flood risk system (determination of current and future flood risk), the evaluation of a certain system state (judgement on risk and risk reduction alternatives) and the reduction of undesirable risk (strategic alternatives for flood risk reduction).

Flood risk assessment is based on "Flood hazard maps"and the resulting „Flood risk assessment maps"made during the first two stages of the risk assessment. Flood hazard maps contain information for flooded areas and flood depth for three flood scenarios with different return periods / probability $\left(\mathrm{HQ}_{20 / 5} \%, \mathrm{HQ}_{100} /{ }_{1 \%}, \mathrm{HQ}_{1000 / 0,1 \%}\right)$. Flood risk assessment maps provide information concerning the potential negative impacts of floods on the protected categories of Human Health, Economic Activity, Environment and Cultural Heritage. (Fig.1)

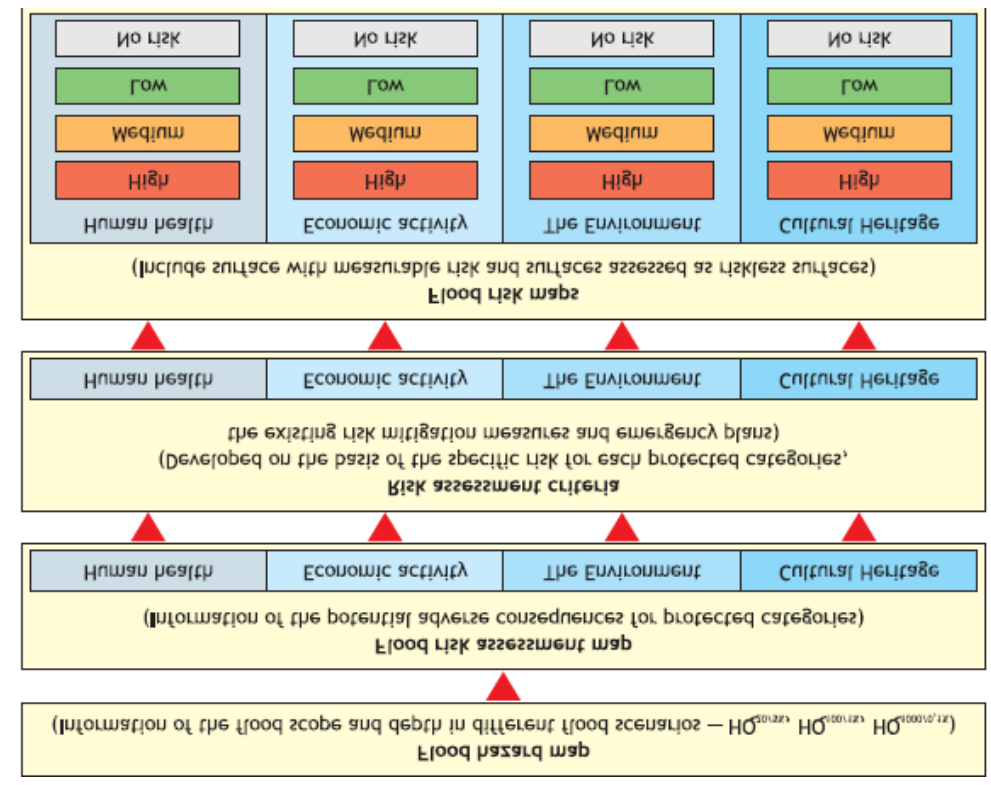

Figure 1. Flood risk assessment algorithm, adapted from [1]

The flood risk is presented in four degrees: high, medium, low risk and no risk. Separate criteria for each degree of risk and each protected category were developed. [2]

\section{RESULTS AND DISCUSSION}

The flood risk assessment for Veliko Tarnovo was made in a GIS by comparing the Flood hazard map[3] and the Map of risk assessment at flood depths $\mathrm{HQ}_{20 / 5 \%}, \mathrm{HQ}_{100} / 1 \%$, $\mathrm{HQ}_{1000 / 0,1 \% .(F i g .2)}$ 


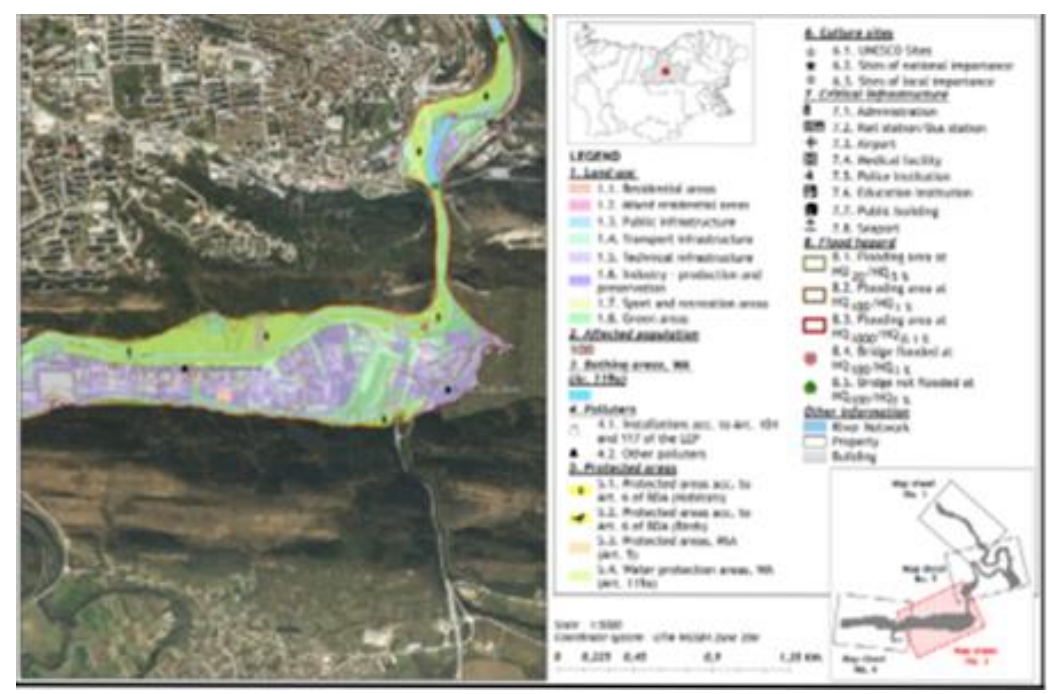

Figure 2. Flood Risk Assessment Map for Veliko Tarnovo

The results obtained for the flood risk are presented in the Risk Map. (Fig.3)

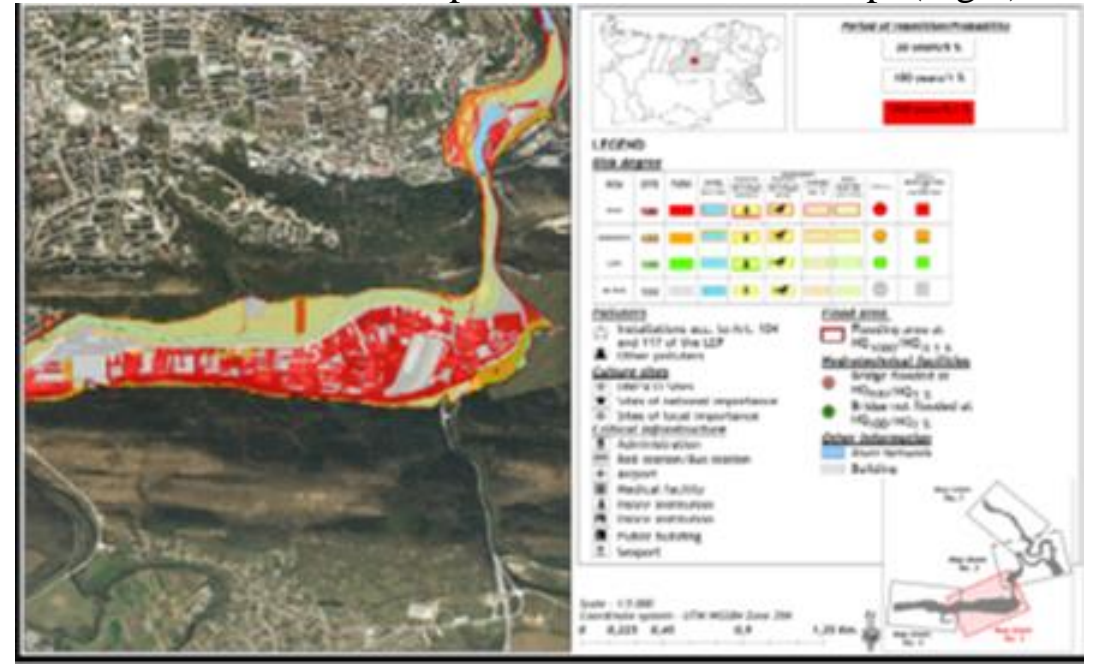

Figure 3. Flood Risk Map for Veliko Tarnovo

\section{ANALYSIS OF THE YANTRA RIVER FLOOD RISK SYSTEM}

The risk is assessed for each of the protected categories: Human Health", "Economic Activity", "Environment" and "Cultural Heritage", and is mapped separately for the three flood scenarios - $\mathrm{HQ}_{20 / 5 \%}, \mathrm{HQ}_{100} / 1 \%, \mathrm{HQ}_{1000 / 0,1 \%}$.Fig.3)

\section{„Human health“"}

The risk assessment for the "Human Health" category uses the indicators "Population"19 and "Critical Infrastructure" 20 . The depth of flooding mainly determines the risk to human health. The affected population and critical infrastructure sites in the three flood scenarios are presented in Table 1.

\footnotetext{
${ }^{19}$ The number of the affected population is calculated directly by the number of persons permanently residing in a given building from the official statistics obtained during the population census.

${ }^{20}$ These are spatially localized locations of medical establishments (hospitals, etc.), educational institutions (schools, kindergartens, homes for children, etc.), public buildings (elderly homes, etc.).
} 
Table 1. Flood risk assessment for the category "Human health"

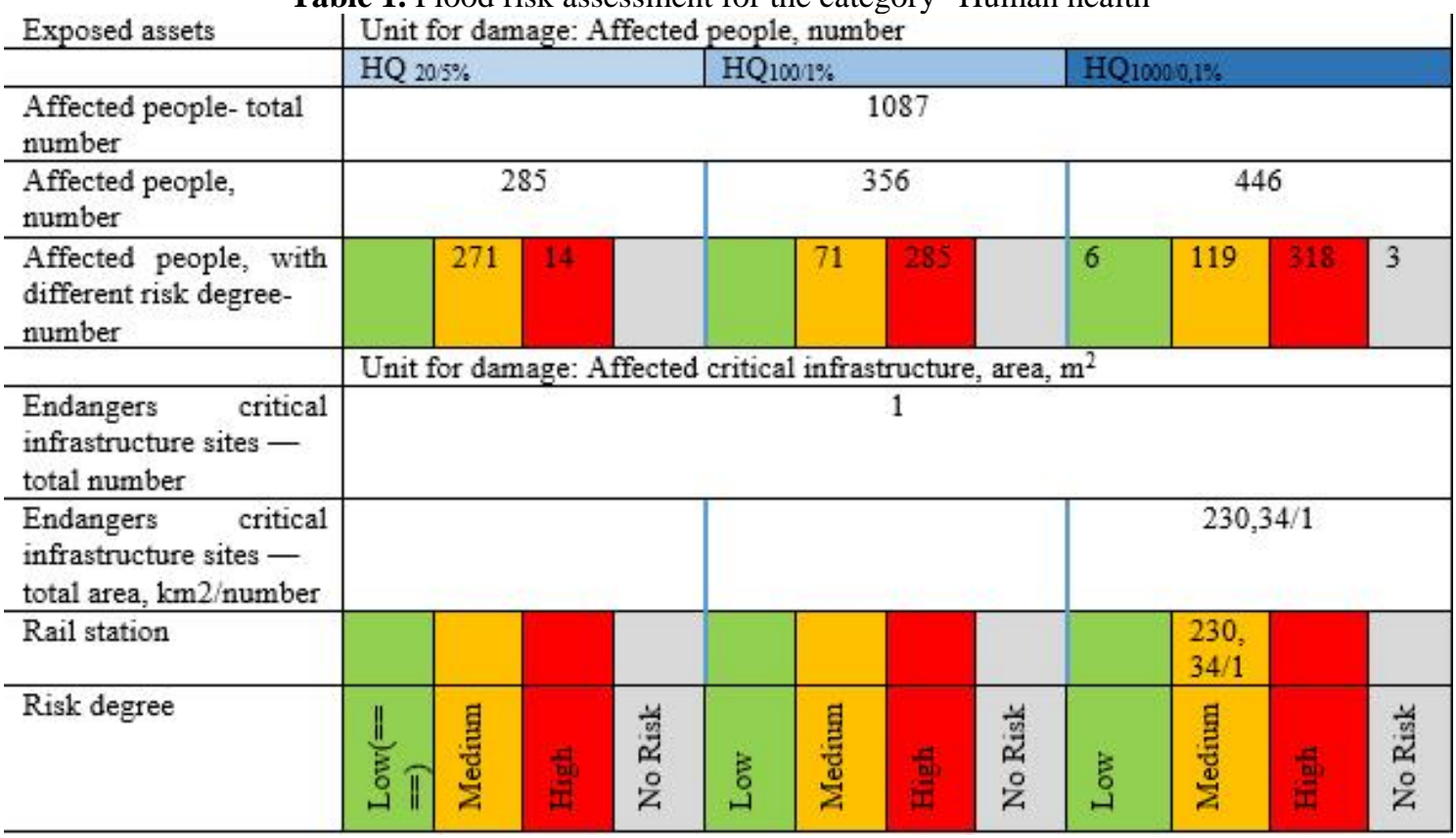

The risk assessment for the category „Human Health“ does not take into account the existing emergency situations planning, for example the evacuation routes or the possibility of vertical evacuation (of higher floors), and also the protection of personal property. No additional factors, such as age structure, marital status, economic status, preparedness to act in an emergency, early warning systems, evacuation plans, etc. were taken into account. Taking into account these factors may lead to a change in the degree of risk. It is also assumed that the adverse effects are the same regardless of the type (eg hospital, primary or secondary school, etc.) and the size (so-called number of hospital beds, number of students, etc.) of the site by the critical infrastructure.

\section{"Economic activity"}

The risk assessment for the "Economic activity" category uses the indicator "Land use" or "Permanently land use“"21. The evaluation is carried out on the eight categories of economic activity presented in Table 2 . It is assumed that the risk is mainly due to the direct impact of floods on production and commercial activity and depends on the depth of flooding.

In all three potentially flooded areas $\mathrm{HQ}_{20 / 5 \%}, \mathrm{HQ}_{100} / 1 \%, \mathrm{HQ}_{1000 / 0,1 \%}$ the land use categories with largest area are: "Green territories" , „Industry - production and storage”, „Transport infrastructure“ "Mixed residential areas" and "Technical infrastructure" The other categories of "Economic Activity" occupy about $1 \%$ of the area of the respective flooded zone. In accordance with the flood depth in all three flood scenarios $\left(\mathrm{HQ}_{20 / 5 \%}\right.$, $\mathrm{HQ}_{100} /{ }_{1 \%}, \mathrm{HQ}_{1000 / 0,1 \%}$.) the areas rated "high" risk have the largest area. This is due to the large relative share of the Green Territory category. For this economic category, however, it is assumed that the risk of flooding, irrespective of the depth of flooding, is generally insignificant as there are usually no buildings and people there. In addition, it must also

${ }^{21}$ It refers to the use of land for various socio-economic purposes - residential, industrial, agricultural, forestry, recreational, transport, etc. objectives (modes of lasting use) that can be transformed into classes of economic activities. 
be taken into account that there is no risk of contamination by installations and facilities operating and storing hazardous substances for these sites. Therefore, this category of the flood risk map is marked as a "no risk" category. For the "mixed residential areas" category, the largest area is assessed as "high" for all flood scenarios while for the "Industry - Production and Storage" and "Transport Infrastructure" categories the area assessed as "High risk" is the largest only for two of the scenarios - HQ $\mathrm{H}_{100 / 1 \%}, \mathrm{HQ}_{1000}$ / $0.1 \%$ ). The assessment does not take into account the risk of destroying transport infrastructure and interrupting access to potentially flooded streets. The additional risks associated with interruptions in the supply of electricity, food and water are also not identified.

Table 2. Flood risk assessment for the category "Economic activity"

\begin{tabular}{|c|c|c|c|c|c|c|c|c|c|c|c|c|c|c|c|}
\hline $\begin{array}{l}\text { Exposed } \\
\text { assets }\end{array}$ & \multicolumn{15}{|c|}{ Unit for damage: Affected area, $\mathrm{km}^{2}$} \\
\hline $\begin{array}{l}\text { Return } \\
\text { period }\end{array}$ & \multicolumn{5}{|c|}{$\mathrm{HQ}_{205 \%}$} & \multicolumn{5}{|c|}{ HQ $1001 \%$} & \multicolumn{5}{|c|}{ HQ10000,1\% } \\
\hline $\begin{array}{l}\text { Total } \\
\text { affected } \\
\text { area, } \mathrm{km}^{2}\end{array}$ & \multicolumn{15}{|c|}{10,977} \\
\hline Affected & \multicolumn{5}{|c|}{3,040} & \multicolumn{5}{|c|}{3,774} & \multicolumn{5}{|c|}{4,163} \\
\hline & 푱 & ?̊. & ํ. & i & & ङే & ڤै & ํ. & ii & & 퐁 & 彳̊ & $\begin{array}{l}\text { ì } \\
\text { ñ } \\
\text { ô }\end{array}$ & 악 & \\
\hline $\begin{array}{l}\text { Residenti } \\
\text { al } \\
\text { areas }\end{array}$ & $\begin{array}{l}0,0 \\
10\end{array}$ & $\begin{array}{l}0,0 \\
01\end{array}$ & $\begin{array}{l}0,0 \\
06\end{array}$ & $\begin{array}{l}0,0 \\
03\end{array}$ & $\begin{array}{l}0,0 \\
00\end{array}$ & $\begin{array}{l}0,0 \\
23\end{array}$ & $\begin{array}{l}0,0 \\
01\end{array}$ & $\begin{array}{l}0,0 \\
09\end{array}$ & $\begin{array}{l}0,0 \\
13\end{array}$ & $\begin{array}{l}0,0 \\
00\end{array}$ & $\begin{array}{l}0,02 \\
6\end{array}$ & $\begin{array}{l}0,0 \\
01\end{array}$ & $\begin{array}{l}0,0 \\
03\end{array}$ & $\begin{array}{l}0,0 \\
22\end{array}$ & $\begin{array}{l}0,0 \\
00\end{array}$ \\
\hline $\begin{array}{l}\text { Mixed } \\
\text { residenti } \\
\text { al } \\
\text { areas } \\
\end{array}$ & $\begin{array}{l}0,1 \\
60\end{array}$ & $\begin{array}{l}0,0 \\
21\end{array}$ & $\begin{array}{l}0,0 \\
61\end{array}$ & $\begin{array}{l}0,0 \\
69\end{array}$ & $\begin{array}{l}0,0 \\
08\end{array}$ & $\begin{array}{l}0,2 \\
09\end{array}$ & $\begin{array}{l}0,0 \\
20\end{array}$ & $\begin{array}{l}0,0 \\
59\end{array}$ & $\begin{array}{l}0,1 \\
21\end{array}$ & $\begin{array}{l}0,0 \\
10\end{array}$ & $\begin{array}{l}0,24 \\
5\end{array}$ & $\begin{array}{l}0,0 \\
17\end{array}$ & $\begin{array}{l}0,0 \\
62\end{array}$ & $\begin{array}{l}0,1 \\
60\end{array}$ & $\begin{array}{l}0,0 \\
06\end{array}$ \\
\hline $\begin{array}{l}\text { Commun } \\
\text { al } \\
\text { infrastru } \\
\text { cture }\end{array}$ & $\begin{array}{l}0,0 \\
13\end{array}$ & $\begin{array}{l}0,0 \\
01\end{array}$ & $\begin{array}{l}0,0 \\
06\end{array}$ & $\begin{array}{l}0,0 \\
06\end{array}$ & $\begin{array}{l}0,0 \\
01\end{array}$ & $\begin{array}{l}0,0 \\
24\end{array}$ & $\begin{array}{l}0,0 \\
02\end{array}$ & $\begin{array}{l}0,0 \\
08\end{array}$ & $\begin{array}{l}0,0 \\
13\end{array}$ & $\begin{array}{l}0,0 \\
00\end{array}$ & $\begin{array}{l}0,03 \\
6\end{array}$ & $\begin{array}{l}0,0 \\
03\end{array}$ & $\begin{array}{l}0,0 \\
11\end{array}$ & $\begin{array}{l}0,0 \\
22\end{array}$ & $\begin{array}{l}0,0 \\
01\end{array}$ \\
\hline $\begin{array}{l}\text { Technica } \\
1\end{array}$ & $\begin{array}{l}0,0 \\
92\end{array}$ & $\begin{array}{l}0,0 \\
02\end{array}$ & $\begin{array}{l}0,0 \\
08\end{array}$ & $\begin{array}{l}0,0 \\
83\end{array}$ & $\begin{array}{l}0,0 \\
00\end{array}$ & $\begin{array}{l}0,0 \\
96\end{array}$ & $\begin{array}{l}0,0 \\
01\end{array}$ & $\begin{array}{l}0,0 \\
04\end{array}$ & $\begin{array}{l}0,0 \\
91\end{array}$ & $\begin{array}{l}0,0 \\
00\end{array}$ & $\begin{array}{l}0,09 \\
7\end{array}$ & $\begin{array}{l}0,0 \\
00\end{array}$ & $\begin{array}{l}0,0 \\
02\end{array}$ & $\begin{array}{l}0,0 \\
95\end{array}$ & $\begin{array}{l}0,0 \\
00\end{array}$ \\
\hline $\begin{array}{l}\text { infrastru } \\
\text { cture }\end{array}$ & & & & & & & & & & & & & & & \\
\hline $\begin{array}{l}\text { Transpor } \\
t\end{array}$ & $\begin{array}{l}0,2 \\
19\end{array}$ & $\begin{array}{l}0,0 \\
34\end{array}$ & $\begin{array}{l}0,0 \\
98\end{array}$ & $\begin{array}{l}0.0 \\
20\end{array}$ & $\begin{array}{l}0,0 \\
16\end{array}$ & $\begin{array}{l}0,3 \\
45\end{array}$ & $\begin{array}{l}0,0 \\
24\end{array}$ & $\begin{array}{l}0,0 \\
04\end{array}$ & $\begin{array}{l}0,1 \\
97\end{array}$ & $\begin{array}{l}0,0 \\
13\end{array}$ & $\begin{array}{l}0,43 \\
25\end{array}$ & $\begin{array}{l}0,0 \\
20\end{array}$ & $\begin{array}{l}0,0 \\
92\end{array}$ & $\begin{array}{l}0,3 \\
12\end{array}$ & $\begin{array}{l}0,0 \\
08\end{array}$ \\
\hline $\begin{array}{l}\text { infrastru } \\
\text { cture }\end{array}$ & & & & & & & & & & & & & & & \\
\hline Industry & $\begin{array}{l}0,5 \\
58\end{array}$ & $\begin{array}{l}0,1 \\
10\end{array}$ & $\begin{array}{l}0,2 \\
82\end{array}$ & $\begin{array}{l}0,1 \\
42\end{array}$ & $\begin{array}{l}0,0 \\
24\end{array}$ & $\begin{array}{l}0,8 \\
23\end{array}$ & $\begin{array}{l}0,0 \\
76\end{array}$ & $\begin{array}{l}0,2 \\
63\end{array}$ & $\begin{array}{l}0,4 \\
64\end{array}$ & $\begin{array}{l}0,0 \\
20\end{array}$ & $\begin{array}{l}0,93 \\
1\end{array}$ & $\begin{array}{l}0,0 \\
31\end{array}$ & $\begin{array}{l}0,1 \\
52\end{array}$ & $\begin{array}{l}0,7 \\
30\end{array}$ & $\begin{array}{l}0,0 \\
18\end{array}$ \\
\hline $\begin{array}{l}\text { Producti } \\
\text { on and } \\
\text { preservat } \\
\text { ion }\end{array}$ & & & & & & & & & & & & & & & \\
\hline $\begin{array}{l}\text { Sport and } \\
\text { recreatio } \\
\mathrm{n} \text { areas }\end{array}$ & $\begin{array}{l}0,0 \\
06\end{array}$ & $\begin{array}{l}0,0 \\
00\end{array}$ & $\begin{array}{l}0,0 \\
03\end{array}$ & $\begin{array}{l}0.0 \\
02\end{array}$ & $\begin{array}{l}0,0 \\
00\end{array}$ & $\begin{array}{l}0,0 \\
10\end{array}$ & $\begin{array}{l}0,0 \\
01\end{array}$ & $\begin{array}{l}0,0 \\
03\end{array}$ & $\begin{array}{l}0,0 \\
0.6\end{array}$ & $\begin{array}{l}0,0 \\
00\end{array}$ & $\begin{array}{l}0,01 \\
1\end{array}$ & $\begin{array}{l}0,0 \\
0\end{array}$ & $\begin{array}{l}0,0 \\
02\end{array}$ & $\begin{array}{l}0.0 \\
09\end{array}$ & $\begin{array}{l}0,0 \\
00\end{array}$ \\
\hline $\begin{array}{l}\text { Green } \\
\text { areas } \\
\end{array}$ & $\begin{array}{l}1,9 \\
83 \\
\end{array}$ & $\begin{array}{l}0,0 \\
92 \\
\end{array}$ & $\begin{array}{l}0,3 \\
34 \\
\end{array}$ & $\begin{array}{l}1,5 \\
27 \\
\end{array}$ & $\begin{array}{l}0,0 \\
29 \\
\end{array}$ & $\begin{array}{l}2,2 \\
45 \\
\end{array}$ & $\begin{array}{l}0,0 \\
71 \\
\end{array}$ & $\begin{array}{l}0,2 \\
56 \\
\end{array}$ & $\begin{array}{l}1.8 \\
81\end{array}$ & $\begin{array}{l}0,0 \\
37 \\
\end{array}$ & $\begin{array}{l}2,38 \\
5 \\
\end{array}$ & $\begin{array}{l}0,0 \\
52 \\
\end{array}$ & $\begin{array}{l}0,2 \\
02 \\
\end{array}$ & $\begin{array}{l}2,0 \\
97 \\
\end{array}$ & $\begin{array}{l}0,0 \\
35 \\
\end{array}$ \\
\hline $\begin{array}{l}\text { Risk } \\
\text { degree }\end{array}$ & & 今. & 悬 & 证 & 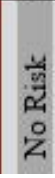 & & לू & 㲘 & 푬 & 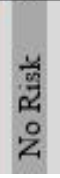 & & 今. & $\frac{\text { 豙 }}{\frac{3}{2}}$ & & $\begin{array}{l}\frac{y}{3} \\
\frac{1}{2} \\
\frac{0}{2}\end{array}$ \\
\hline
\end{tabular}




\section{"Environment"}

For risk assessment for the "Environment" category two indicators are used "Environmental pollution (sources of pollution with hazardous substances)"22 и "Environmental protection (protected areas)"23. Concerning the risk of pollution, five socalled "other pollutants" have been indicated: "24 - Wastewater Treatment Plant (WWTP) of Veliko Tarnovo and the industrial enterprises: Terem-Ivailo ltd, KronoshpanBulgaria ltd, Bitova Electronica and Boliarka ltd. According to the developed methodology, the identified sources are assessed with an "medium" risk of environmental pollution for all flood scenarios $\left(\mathrm{HQ}_{20 / 5} \%, \mathrm{HQ}_{100} / 1 \%, \mathrm{HQ}_{1000 / 0,1 \%}\right)$. (Table.3)

Table 3. Flood risk assessment for the category \$Environment

\begin{tabular}{|c|c|c|c|c|c|c|c|c|c|}
\hline Exposed assets & \multicolumn{9}{|c|}{ Unit for damage } \\
\hline & \multicolumn{9}{|c|}{ Affected objects, area/number } \\
\hline Return period & \multicolumn{2}{|c|}{$\mathrm{HQ}_{20.5 \%}$} & \multicolumn{3}{|c|}{$\mathrm{HQ}_{100 / 1 \%}$} & \multicolumn{4}{|c|}{$\mathrm{HQ}_{10000,1 \%}$} \\
\hline & \multicolumn{9}{|c|}{ Polluters } \\
\hline Total number/ total area, $\mathrm{km} 2$ & \multicolumn{9}{|c|}{ 5/n.d } \\
\hline \multicolumn{10}{|l|}{$\begin{array}{l}\text { Enterprises under Art. } 104 \text { (1), } \\
\text { EPA }\end{array}$} \\
\hline \multicolumn{10}{|l|}{$\begin{array}{l}\text { Installations and facilities } \\
\text { under Art. } 117 \text { of EPA }\end{array}$} \\
\hline Other polluters & & 1 & & & 2 & & & 4 & \\
\hline & \multicolumn{9}{|c|}{ Protected areas } \\
\hline $\begin{array}{l}\text { Protected areas - number/ total } \\
\text { area, } \mathrm{km} 2\end{array}$ & \multicolumn{9}{|c|}{$2 / 5.513$} \\
\hline Affected area - protected, $\mathrm{km} 2$ & \multicolumn{2}{|c|}{$2 / 1,668$} & \multicolumn{3}{|c|}{$2 / 1,858$} & \multicolumn{4}{|c|}{$2 / 1,987$} \\
\hline $\begin{array}{l}\text { Protected areas from the European } \\
\text { ecologic network NATURA } \\
2000 \text {, in accordance with } \\
\text { Art. } 6 \text { of the BDA (habitats and } \\
\text { birds), } \mathrm{km} 2\end{array}$ & 1,619 & 0,049 & & 0,560 & 1,240 & 0,058 & 0,424 & 1,500 & 0,062 \\
\hline Risk degree & לั & 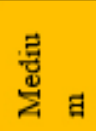 & 点 & לั & 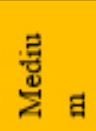 & 营 & לั. & 莺 & 皇 \\
\hline
\end{tabular}

Potentially flooded areas include parts of two Natura 2000 protected areas - Turnovo heights and Yantra River. The risk for them is assessed as "low" for all flood depths and flood scenarios $\left(\mathrm{HQ}_{20 / 5 \%}, \mathrm{HQ}_{100} / 1 \%, \mathrm{HQ}_{1000 / 0,1 \%}\right)$. However, due to the danger of contamination by hazardous chemicals from industrial plants, in the event of flooding, the degree of risk increases and for part of the territory of the protected areas, it is assessed as "medium". After WWTP of the town of Veliko Tarnovo, the risk for the protected area "Yantra River" is growing and is assessed as "high risk". (Fig.3) The environmental pollution risk of Veliko Tarnovo may be reduced if it is established that preventive measures are planned by identified plants - potential pollutants - to ensure that the

${ }^{22}$ Environmental pollution represents the wide spread/ prevalence of polluting and dangerous substances as a result of flooding, which can cause pollution of the environment or some of its components.

${ }^{23}$ The protection of the environment represents the wildlife/natural areas, which are of great importance for the preservation of human health and the biodiversity of a given territory.

${ }^{24}$ Other pollutants" include potentially hazardous objects which in the event of flooding pose a potential hazard to human health and the environment - sewage treatment plants/wastewater treatment plants (WWTPs), sewage disposal facilities in the sewage system, gas stations, etc. 
distribution of pollutants can be limited, and these measures are included in their contingency plans.

\section{Cultural Heritage}

The "Cultural Heritage" indicator is used for the risk assessment ${ }^{\star 25}$. For each cultural site located within potentially flooded areas, a risk assessment has been carried out using a matrix that takes into account the likelihood of flooding $\left(\mathrm{HQ}_{20 / 5} \%, \mathrm{HQ}_{100} /{ }_{1 \%}, \mathrm{HQ}_{1000 / 0,1 \%}\right.$.) and the depth of flooding.(Table 4)

Table 4. Flood Risk Assessment for the "Cultural Heritage" category

\begin{tabular}{|l|l|l|l|l|}
\hline $\begin{array}{l}\text { Period } \\
\text { frequency }\end{array}$ & HQ20/5\% & HQ100/1\% & HQ1000/0,1\% \\
\hline Depth, m & & 3 & 2 & 1 \\
\hline $0,00-0,25$ & 1 & Church & & \\
\hline $0,25-1,0$ & 2 & $\begin{array}{l}\text { Dormition of the Theotokos } \\
\text { Church; } \\
\text { Holy Forty Martyrs Church }\end{array}$ & $\begin{array}{l}\text { Church; } \\
\text { Holy Forty Martyrs Church; } \\
\text { Dormition of the Theotokos } \\
\text { Church }\end{array}$ & $\begin{array}{l}\text { Paul; } \\
\text { Church of Saint Peter and } \\
\text { Holy Forty Martyrs Church; } \\
\text { Dormition of the Theotokes } \\
\text { Church }\end{array}$ \\
\hline$>1,00$ & 3 & & & \\
\hline
\end{tabular}

At the same time, for a more detailed assessment of cultural and scientific value and public significance, immovable cultural values are also assessed in terms of whether they are part of the world cultural heritage (UNESCO sites) or are sites of national or local importance

The specified degree of risk can be increased (e. g information on high vulnerability to cultural values to moisture, etc.) or reduced (e.g if there is information on the resiliency/ flood resistance/ of the building and / or the availability of additional means to protect the cultural heritage in it)

\section{Strategic alternatives for flood risk reduction}

The flood risk assessment under different scenarios ( $\mathrm{HQ}_{20 / 5} \%, \mathrm{HQ}_{100} /_{1 \%}, \mathrm{HQ}_{1000 / 0,1 \%}$.) indicates that there is a "high" risk for the four assessed categories. It allows the application of various structural and non-structural measures to limit the risk, covering the periods before, during and after the flood event, and which are aimed at reducing (preventing) the potential impact of floods occurring and reducing (mitigating) the consequences. These measures are - upstream watershed changes(activities related to the increase of the forest area, mainly in the flat part of the basin), introduction of zoning in spatial planning (related to legislative measures to limit economic activity in high risk areas), emergency planning (preparation of adequate plans for the protection of the population based on the risk assessment), preparedness (awareness-raising and preparedness activities of the population in flood risk areas for adequate response), structural measures (related to construction of dykes and corrections of river sections for the protection of important economic sites).

\footnotetext{
${ }^{25}$ Cultural heritage" covers immovable material heritage, which is a collection of cultural values that bear the historical memory, national identity and have scientific or cultural value.
} 


\section{CONCLUSION AND/ RECOMMENDATIONS}

As a result of the survey, the flood risk for Veliko Tarnovo was assessed. However, the applied methodological approach has a number of limitations as described in the risk assessment of the individual protected categories. They result from the fact that the assessment is made mainly taking into account the depth of the water and the return period / probabilities. To improve the accuracy of the risk assessment it is also necessary to use additional documented local information related to the applied risk mitigation measures as well as the existing emergency response plans in case of flooding. In this sense, the accuracy of the risk assessment depends largely on the knowledge and experience of local stakeholders (local authorities, residents, NGOs, businesses, etc.).

\section{REFERENCES}

[1] Hochwasserris ikomanagement planung in Baden-Württemberg. Ministerium für Umwelt, Klima und Energiewirtschaft Baden-Württemberg, Germany (Stuttgart), 2013;

[2] Zlatunova, D. Chapter Five: Flood risk assessment and mapping. In Methodology for Flood Risk Assessment. Bulgaria (University of Veliko Turnovo), 2014, pp. 56;

[3] Markov, I, D. Zlatunova. Flood hazard to the town Veliko Tarnovo. Proceedings fourth international scientific conference: climate change, economic development, environment and people conference (CCEDEP). Regional development of Central and Eastern European countries. Academic Publishing House "Talent" University of Agribusiness and Rural Development Bulgaria 2015, pp.394. 